\title{
ESTIMATION OF ZAKAT PROCEEDS IN BANGLADESH: A TWO-APPROACH ATTEMPT
}

\author{
Rashed Jahangir ${ }^{1}$ and Mehmet Bulut ${ }^{2}$ \\ ${ }^{1}$ Department of Islamic Economics and Finance, Istanbul Sabahattin Zaim University, Istanbul, \\ Turkey, rashed3355@gmail.com \\ ${ }^{2}$ Department of Islamic Economics and Finance, Istanbul Sabahattin Zaim University, Istanbul, \\ Turkey, mehmet.bulut@izu.edu.tr
}

\begin{abstract}
The purpose of this study is to calculate Zakat proceeds in Bangladesh by using both classical and contemporary or alternative Zakat calculation methods. The results reveal that the percentage of Zakat amount to GDP is significantly higher than the average, i.e., 2.5-3\%; under the classical and alternative approaches, the Zakat proceeds are estimated as 3.79 and 2.33 percent of GDP, respectively.
\end{abstract}

Keywords: Zakat, Economic growth, Poverty alleviation, Islamic social finance.

JEL classification: B55; E6; H2; I38.

Article history:

Received : : August 28, 2021

Revised : February 2, 2022

Accepted : February 27, 2022

Available online : February 28, 2022

https://doi.org/10.21098/jimf.v8i1.1455 


\section{INTRODUCTION}

This section discusses the background and problem of the study by providing a brief scenario of poverty level, few initiatives that have been taken for poverty alleviation, and how researchers have portrayed the subject in recent years, and finally, by discussing the potential of Zakat as an instrument to minimize the poverty in Bangladesh.

\subsection{Background}

Poverty has long been an unsettling societal issue in Bangladesh, as it is in many other nations. Approximately 82 percent of the people lived in poverty shortly after independence (Khatun, Shaon \& Sadekin, 2021). Since then, Bangladesh has made tremendous progress in alleviating poverty. Over the last three decades, poverty alleviation has become a buzzword in Bangladesh. There are many academic and non-academic endeavors concentrating on this issue and ascertaining efficient and effective solutions to ameliorate the condition. Based on two prominent research databases-i.e., Scopus (45) and Web of Science (39) - a total of 84 articles were published over 2019-2021 focusing on poverty issues. An illustrative list of these articles include Adnan et al., 2020; Maîtrot et al., 2021; Mizanur Rahman, 2019; Rahman et al., 2021; Sarker et al., 2020; Sydunnaher et al., 2019.

Along with academic contributions, several initiatives and programs have been implemented by many institutions, public and private, to reduce the poverty rate. According to the Asian Development Bank (ADB), the poverty rate in Bangladesh dropped from 24.3 percent in 2016 to 20.5 percent in 2019.

In response to poverty, as mentioned earlier, various initiatives have been undertaken. The country launched one Two-Year Plan and five Five-Year Plans, and a Three-Year PRSP (Poverty Reduction Strategy Paper) Rolling Plan to alleviate poverty and boost economic growth. Programs like Microcredit and Safety Net Program have a significant contribution in alleviating the poverty rate; however, it has also been noted that these two instruments or programs are not successful in reducing the income inequality gap (Khan, 2009). Hassan \& Khan (2007) mention the failure of the microcredit system in order to reduce social inequality. Mesbahuddin (2010) even takes one step further, claiming that the microcredit program causes various religious conflict and tension in the rural area, and this program mostly depends on the donors, local and foreign, which denotes a sense of inclined attitude towards the donors. Momen \& Begum (2006) criticize the higher compound interest policy of the microcredit program.

On the contrary, the Zakat system is unique, and it is the only special scheme that provides financial support without any interest for the extremely needy community. Besides, it can also contribute to the government taxation system by increasing the employment rate, productivity, and output (Hassan \& Khan, 2007). As a result, several economists project that "potential Zakat funds could have contributed up to $43 \%$ of the annual development plan of Bangladesh in the fiscal year 2004-2005. For example, the GDP of Bangladesh was US $\$ 163.72$ billion (using purchasing power parity, PPP) in 2005, and the Muslim population was $88 \%$; therefore, the adjusted GDP for the purpose of Zakat estimation was US\$144.08 billion" (Shirazi, Amin \& Anwar, 2009). 
It is worth mentioning that the concept of Zakat is not new in Bangladesh. As the third-largest Muslim nation in the world, the term Zakat is widely known to the people of Bangladesh; however, the scenario is quite different regarding its practice. People firmly believe in Zakat as the third pillar of Islam, but the seriousness of giving Zakat is not well established in society as the other four pillars. As a result, the absence of a solid framework of the official Zakat board, which is supposed to direct the administrators for the collection and distribution of Zakat, is conspicuous.

This absence creates a trust gap between individual Zakat givers and the authority. Even institutional participation is quite limited. In Bangladesh, the collection of Zakat reached BDT 110 billion or \$1.4 billion in 2010 ( $1.4 \%$ of GDP). Out of this amount, the government-run Zakat board collected only BDT 14.2 million (Star Business Report, 2014). Surprisingly, one of the estimations of the Zakat board shows the Zakat "collection of 42 commercial banks where only 14 had collected an amount of BDT 60 million during 2012-2013 annually but the board distributed only BDT 2 million. Out of the 42 banks, the remaining 28 commercial banks did not put an effort on Zakat collection despite having separate accounts and a collection of over BDT 10 million each; however, they had no accountability list of the funds" (Uddin, 2016).

Regarding the distribution of Zakat, Bangladesh has a dual Zakat management system. There is no official obligation to pay the Zakat; rather, it is practiced as voluntary work. If anyone wants to pay Zakat, they can either pay through Islamic Foundation's Zakat Board, a government agency under the ministry of religious affairs, or to other private institutional collectors, such as CZM, or even to individuals who can mobilize the Zakat proceeds of individuals. Interestingly, the individual payer of Zakat mostly prefers to distribute their Zakat proceeds by providing two gender's clothing-i.e., 'Sharee' for female and 'Lungi' for males. Even some people distribute edible dry products as Zakat payments which last only for three to four days (Uddin, 2016). On the other hand, the distribution through the institution is quite different from the traditional distribution culture of Bangladesh. They distribute the collected Zakat proceeds through various scholarship programs for needy students, empowering women through different training, housing for needy people, providing rickshaws to unemployed young individuals, and widows' rehabilitation (Star Business Report, 2014).

Based on the aforementioned discussion, two points are obvious regarding the context of Bangladesh: first, the poverty problem and its necessity to alleviate it, and second, the self-sustainable nature and potential of Zakat. These points motivate the study to estimate the Zakat in Bangladesh.

\subsection{Objective}

While Bangladesh is eager to alleviate the poverty rate, it has never seriously looked at the Zakat program as a national poverty reduction strategy. For instance, the Zakat program was not included in the program of poverty alleviation in the fiscal year 2012-2013 (Bangladesh Ministry of Finance, 2012). For this reason, this study reemphasizes the necessity of Zakat collection by estimating the Zakat proceeds of Bangladesh with a proposition to reconsider the Zakat program as 
their poverty reduction program. The main objective of this research is to calculate the Zakat proceeds by using two different approaches.

The remainder of the paper is organized as follows. Section 2 reviews previously conducted research on Zakat estimation and its contribution to poverty contribution and economic development. The calculation of data and methods of Zakat proceeds and statistical analysis methodology is explained in section 3. Section 4 illustrates the estimated result of Zakat proceeds and elucidates the analysis of Zakat and the economic development scenario. Finally, section 5 concludes by providing recommendations.

\section{LITERATURE REVIEW}

There have been numerous studies focusing on Zakat ranging from the concept of Zakat, its measurement and more recently its relation to the economy. In this section, we review representative studies on the measurement of Zakat proceeds and few studies on the relations between Zakat and economic growth.

Kahf (1987) provids and discusses few studies that estimate the potential Zakat proceeds in some Muslim countries. He refers to an estimation of Zakat proceeds (up to 6.1 percent of the GDP) of Egypt by Sami Ramaadan Suliman in 1973, which he deems an overestimation. On the other hand, an estimation of Zakat proceeds (3.0 percent of GDP) in 1982 for Sudan is calculated by Muhammad Hussain Awad, which he considers underestimated. Moreover, Kahf also discusses two other Zakat proceeds estimation for Saudi Arabia (2.7 percent of the GDP) and Kuwait (2.1 percent of GDP) by Muqbil Zuqair and Faud al Omar respectively (Shirazi, 2006).

Adnan \& Bakar (2009) review the treatments of corporate Zakat from an accounting point of view based on accounting guidelines and standards (e.g., Financial Accounting Standard No. 9 and the Technical Release i-1). They find a general misconception of Zakat regarding standards and guidelines that consequently led to inappropriateness in the measurement and recognition of their proposed corporate Zakat as well as in its presentations. The connection between Zakat and accounting has garnered extensive discussion in the literature, see inter alia Adnan \& Bakar (2009); Al-Habshi (2005); Al-Moghaiwli (2001); Bahari \& Hamat (2004); Abu Bakar (2007); Islahi \& Obaidullah (2004); Khan (1994); Mursyidi (2003); Rahim \& Rahman (2007); and Sulaiman (2003).

Razak et al. (2013) apply the Exponential Model, Polynomial Model, and the Discrete Malthusian Growth Model to analyze the Zakat collection trend from Pusat Zakat Melaka (PZM) during the year 2000 - 2009 in Malaysia. Firdaus et al. (2012) estimate Zakat potential for Indonesia and ascertain the correlation between Zakat payment and demographic characteristics. The outcomes reveal that the Zakat proceeds stand at 3.4\% of GDP in Indonesia.

Shirazi (2006) investigates the elimination of poverty in low-income Muslim countries by estimating the potential Zakat amount and resource deficit. In this case, he considers the Zakatable items, with some adjustment defined by Monzer Kahf. Zarqa (2002) claims, "an estimation of potential Zakat proceeds in a contemporary Islamic economy at about 3.00 percent to 3.60 percent of the GDP". However, another study with a similar objective find that the contribution of Zakat proceeds 
could reach $7 \%$ of GDP in Pakistan, mentioning the percentage is adequate to eliminate the poverty gap in the county (Shaikh, 2015). Furthermore, for Pakistan, Kahf (1989) uses diverse categories of Zakat; according to his estimation, the collected Zakat fund can be between "1.6\% of GDP to $4.4 \%$ of GDP".

Hassan \& Khan (2007) indicate possible replacement of government budgetary expenditures from 21\% of Annual Development Plan (ADP) in 1983-84 to 43\% of ADP in 2004-2005 by Zakat fund. On the other hand, to change the status from hard-core households to non-poor, $73 \%$ of annually estimated potential Zakat proceeds will be required in Malaysia (Sadeq, 1996). Awad (1989) estimates onethird of GNP (about 3 to 4 percent of GNP as Zakat revenue) in Sudan could be redistributed to poor people in a decade collected from the wealthy. However, few studies regarding Saudi Arabia and Sudan estimate that the Zakat proceeds would not be more than 1 to 2 percent of GNP, when all the existing Fiche rules are followed (Kahf, 1989; Salama, 1990).

More recently, several studies have been conducted to find out the relationship between Zakat and economic growth in different countries. For example, Khasandy \& Badrudin (2019) claim that Zakat has no impact on economic growth or social wellbeing in Indonesia. However, Suprayitno (2020) find the opposite, i.e. Zakat distribution has a positive impact on economic growth. Similarly, Ben Jedidia \& Guerbouj (2021) also ascertain that Zakat promotes the growth of a nation by increasing consumption, investment, and government spending. A similar finding is also made by Mohamad, Hussin \& Mohamad, (2020) regarding several states in Malaysia.

Along the lines of these studies, this study focuses on estimating the potential Zakat proceeds as a percentage of GDP, given that ascertaining the potential Zakat proceeds would be relevant for poverty alleviation and economic progress.

\section{DATA AND METHODOLOGY}

\subsection{Data}

Both primary and secondary data are used to calculate Zakat proceeds in Bangladesh. This study considers the total number of households (except the number of non-muslim households, which is almost $10 \%$ of the total population) for calculating the total value of gold that belongs to the households. To obtain the estimated amount of gold that belongs to the households, the study interviews ten interviewees in Bangladesh (from 7 districts-i.e., Dhaka, Sherpur, Feni, Rajshahi, Mymensingh, Rajbari, and Pirujpur) via three online platforms-i.e., Skype, Facebook, and WhatsApp, by using random sample technique. The rest of the value of Zakatable items are collected from the Bangladesh Economic Review published by the Ministry of Finance and National Accounts Statistics published by the Bangladesh Bureau of Statistics. On the other hand, the gross domestic product (GDP) is from the World Bank's official website. Due to data availability, this study selects 2018 as the base year for Zakat proceeds estimation. After ollecting and estimating Zakat proceeds, a forecasting method is used based on Bangladesh's annual growth rates. 


\subsection{Method for Zakat Calculation}

Various methods for the calculation of Zakat proceeds have been suggested by scholars and experts. Kahf (1989) estimates Zakat proceeds for eight Muslim countries by considering National Income Account (NIA). Regarding the Zakatable items, he uses three different opinions of jurists known as Z1, Z2 and Z3. "Z1 [is] estimated in accordance with the majority traditional view according to which Zakat was levied on agriculture, livestock, stock in trade, gold, silver and money. Z2 [is] based in accordance with the views of contemporary Muslim scholars where Zakat can be deducted from net returns of manufacturing concerns and building rents and from net savings out of salaries. Z3 [is] based on Malikite views, where Zakat base includes buildings and other fixed assets except those assigned for personal and family use" (Monzer Kahf, 1989). Al-Qaradawi (1999) uses analogical reasoning (qiyas) methodology regarding the new form of wealth in the current world-e.g., bank deposits and financial securities like bonds and shares are also Zakatable. Abu Bakar (2007) also recommend that "the 'illah' for Zakatability should no longer be productive property, but any property which is in excess of one's personal use".

Analyzing different methods is not the objective of this study. As noted, the present study focuses on estimating Zakat proceeds in Bangladesh. The study mainly considers two approaches-i.e., i) classical approach and ii) alternative approach. Kahf (1989) and Khan (1994) mostly comply with the alternative approach, as mentioned in a study conducted by Shaikh (2015). This study particularly follows the methods that Shaikh (2015) apply to estimate the Zakat proceeds in Bangladesh. One of the main reasons behind the selection of the method is the regional similarities. Most of the items used in the study to calculate Zakat are pertinent to the Bangladesh economy. It is noticeable that all the items are not subject to Zakat; only some specific items are considered Zakatable.

Before discussing Zakatable items, understanding the concept of Nisab will develop the solid ground for Zakat proceeds calculation. Nisab is defined as "the minimum amount that determines the Zakatability of a person. The individual who owns nisab is a Zakat payer. He must pay Zakat for all that he owns. Thus, nisab is not exempted from Zakat. Nisab differs from one Zakatable item to another" (Kahf, 1980). Zakatable items are mentioned in various studies and fiqhi books; however, new Zakatable items are not mentioned in many current studies, which is necessary to point out and comprehend. Following are considered new Zakatable items: business net worth, rental buildings, financial investment, financial savings, excess residence, excess transportation, excess decorative items, other excesses (Kahf, 1987).

As mentioned earlier, there has been an institutional gap in Bangladesh. Historically, the Bangladesh Islamic Foundation plays an important role in the Zakat collection; however, many other private institutions have begun to collect this proceeds. The CZM is one of the prominent organizations among them which has categorized Zakatable items into ten sections: Zakat on gold (2.5\%), Zakat on precious stones $(2.5 \%)$, Zakat on silver (2.5\%), Zakat on cash in hand /bank $(2.5 \%)$, Zakat on loans/investments/ funds/ shares, etc. (2.5\%), Zakat on a landed property $(2.5 \%)$, Zakat on business (2.5\%), Zakat on share in partnership firms (2.5\%), Zakat on agricultural produce $(10 \%, 7.5 \%, 5 \%)$, and Zakat on animals \& poultry \& fish 
farming (1 Animal or Bird PER 40 either in kind or value thereof). Noticeably, a common category for other countries, known as "Zakat on livestock", is absent in Bangladesh. One of the scholars in Bangladesh state that the livestock is mostly fostered for business purposes instead of personal use in Bangladesh. For this reason, the livestock is considered under tradable inventory in Bangladesh for Zakat calculation. On the other hand, the classical method of Zakat proceeds estimation does not separate income from wealth, whereas Al-Qaradawi and Kahf have a different view regarding this income.

\section{RESULTS AND DISCUSSION}

This section of this study provides the estimated Zakat amount. It deliberates the nisab amount, the value of gold, and Zakat amount of the two approaches.

\subsection{Zakat Estimation}

Nisab Calculation

Nisab amount is calculated based on the price of gold (per/gram). According to the CZM in Bangladesh, the price of gold per gram is 4975, and the amount of nisab is 85 grams of gold. However, in Bangladesh society, bhori is used instead of gram; 7.5 bhori is the nisab amount.

Table 1.

Nisab Calculaiton

\begin{tabular}{lc}
\hline Particulars & Amount \\
\hline Price of gold/gram & 4975 \\
The Zakat Nisb in gold & 85 \\
Value of Nisab/unit & 422875 \\
Number of families & 3811036 \\
The Nisab value (million BDT) & $1,611,592$ \\
\hline Source: Authors Computation &
\end{tabular}

Source: Authors Computation

\section{Zakat on Gold}

The reason behind mentioning only gold, not silver, is because of the common practice in Bangladesh. People mostly prefer holding gold instead of silver. Collecting microdata regarding individual households holding gold is quite cumbersome. This is because of the unwillingness to share the data with others. People do not feel secure sharing information regarding the amount of gold they possess. For that reason, the gold data for this study is based on a small survey (details in the methodology section). It mainly considers the urban household numbers who are the owner of the house. According to the 2011 census, the total urban household is 7,502,040; where 50.8\% owned the house, others are either rented or rent-free. Based on the survey, the study assumes to have 117 grams of gold in each household which is close to the mean value of the survey result. Table 2 shows the amount in gold. 
Table 2.

Total Amount of Gold

\begin{tabular}{lc}
\hline Particulars & Amount \\
\hline Total Urban Households & $7,502,040$ \\
Total Households (Urban, Owned) & $3,811,036$ \\
Gold Holdings (Grams) Per Housing Unit & 117 \\
Total Amount of Gold in Grams & $445,891,212$ \\
Price of per Gram Gold (BDT) & 4,975 \\
Amount of Gold Value (Amount in million BDT) & $2,218,309$ \\
\hline Source: Authors Computation &
\end{tabular}

\section{Zakat on Agriculture}

Bangladesh is a country primarily based on agriculture. However, the shift from agriculture to the textile industry has been noticeable in recent years. Agriculture land is not Zakatable items as mentioned earlier; however, the produce is Zakatable. "The production from irrigated lands shall be subject to a $5 \%$ levy. The production from rain-fed lands shall be subject to Ushr (i.e. a 10\% levy)" (Shaikh, 2015).

\section{Zakat on Livestock}

Fostering livestock is common in most rural households in Bangladesh; however, it is absent in urban areas. As mentioned earlier, when a local scholar was asked about the livestock, he replied that livestock is not a separate item for Zakat calculation in Bangladesh; it is mainly calculated under the tradable inventory section. The reason behind this is the people's practice, and they have livestock firms for small and medium business purposes. However, to make it more straightforward, the study separates livestock items and presents them in both Zakat calculation approaches.

\section{Zakat on Value of Produce}

To calculate the Zakat on value of produce, the absolute value of all assets such as bank deposits, cash, investments of the mutual fund, equity investments, investment of fixed income securities, investments or annuities are selected in the classical approach. In this case, a $2.5 \%$ rate of Zakat is applied to all these items. Besides, Bangladesh market capitalization is used to estimate the Zakat on the outstanding amount of national savings schemes, stocks, and mutual funds (Shaikh, 2015).

\section{Zakat on Tradable Inventory}

As with other items of Zakat, the exact data on tradable inventory is also cumbersome to manage and estimate. In order to calculate this section, the study considers "change in inventory" for national income, which represents "the value of production in a particular year that remains unsold during that year" (Shaikh, 2015). In both Zakat approaches, a 2.5\% rate is used in order to calculate the Zakat on it. 
Table 3.

Zakat Estimation Based on Classical Approach (million BDT)

\begin{tabular}{lcc}
\hline Category & Amount & Estimated Zakat \\
\hline Gold & $2,218,309$ & \\
Money in Circulation & $2,728,960$ & \\
Money in Deposit Accounts & $4,749,553$ & \\
Bangladesh Market Capitalization & $6,589,892$ & \\
Net Foreign Exchange Reserves with Bank & $2,810,007$ & \\
Change in Stock/Inventories & $7,043,962$ & \\
Outstanding Amount in National Savings Scheme & $6,283,000$ \\
Livestock (Cattle) & 24.2 & \\
Livestock (Sheep) & 3.5 & \\
Livestock (Buffalo) & 1.4 & \\
Livestock (Goat) & 26.2 & \\
Poultry (Chicken and Duck) & 347.03 & \\
(A) Total Wealth Value & $32,423,738$ & \\
(B) Nisab amount & $1,611,592$ & \\
Net amount subject to Zakat (A-B) & $30,812,146.5$ & \\
\hline Total Zakat on Wealth (2.5\%) & & \\
Agriculture Produce & $2,273,520$ & \\
Total Zakat on Agriculture Produce (5\%) & & \\
\hline Total Estimated Amount of Zakat & & $3.733,676$ \\
Total Gross Domestic Product (GDP)-2018 & $23,331,571$ & \\
Zakat to GDP Ratio in Classical Method & & \\
\hline Source: Authors Computation & & \\
\hline
\end{tabular}

Source: Authors Computation

As mentioned earlier, Zakat turnover and collection are relatively low in Bangladesh; even the estimated amount was shown comparatively low before, which has already raised questions among scholars and economists. However, the calculation in this study finds quite (based on classical approach) a higher amount of estimated Zakat, almost a billion BDT in 2018. This amount represents $3.79 \%$ (Table 3) of Bangladesh's GDP, which is logical (Kahf, 1989; Shaikh, 2015). Noticeably, the percentage is lower using the alternative approach, which is $2.33 \%$ (Table 4). One of the main reasons behind this is the rate (according to Monzer Kahf, market capitalization, money in deposit account, and outstanding amount in National Savings Scheme are not subject to Zakat, only their profits ${ }^{1}$ are subject to Zakat at $5 \%$ rate) and Zakatable items; besides, the Zakat rate also plays a significant role in regards to this difference. For instance, in the classical approach, a $2.5 \%$ rate is levied on some items, i.e., market capitalization, but $5 \%$ in the alternative approach.

Between these two approaches, the classical approach estimates higher Zakat proceeds. However, there is room for debate that cannot be avoided; several

\footnotetext{
1. The study calculates the profits of these particulars based on following rate: $13.19 \%$ rate of 5 years Bangladesh Savings Certificate on market capitalization and outstanding amount in National Savings Scheme (Bangladesh National Portal), and maximum 6\% savings deposit rate on money in deposit account (Banagldesh Bank)
} 
Fuqaha or Shariah scholars believe in complying with the classical approach. Though, in Islam, the number does not decide whether something is permissible or otherwise.

Table 4.

Zakat Estimation Based on Alternative Approach (million BDT)

\begin{tabular}{lcc}
\hline Category & Amount & Estimated Zakat \\
\hline Gold & $2,218,309$ & \\
Money in Circulation & $2,728,960$ & \\
Net Foreign Exchange Reserves with Bank & $2,810,007$ & \\
Change in Stock/Inventories & $7,043,962$ & \\
Livestock (Cattle) & 24.2 & 3.5 \\
Livestock (Sheep) & 1.4 \\
Livestock (Buffalo) & 26.2 \\
Livestock (Goat) & 347.03 \\
Poultry (Chicken and Duck) & $14,801,293$ \\
(A) Total Wealth Value & $1,611,592$ & \\
(B) Nisab amount & $13,189,701.5$ & \\
Net amount subject to Zakat (A-B) & & $329,742.54$ \\
Total Zakat on Wealth (2.5\%) & 869,207 & \\
Bangladesh Market Capitalization & 284,973 & \\
Money in Deposit Accounts & 828,728 & \\
Outstanding Amount in National Savings Scheme & $2,273,520$ & \\
Agriculture Produce & $19,895,965$ & \\
Net amount subject to Zakat & & $212,821.3817$ \\
\hline Total Zakat on Income and Agriculture Produce(5\%) & & $542,563.92$ \\
Total Estimated Amount of Zakat & $23,331,571$ & \\
Total Gross Domestic Product (GDP)-2018 & & $2.33 \%$ \\
Zakat to GDP Ratio in Alternative Method & & \\
\hline
\end{tabular}

Source: Authors Computation

\section{Descriptive Analysis}

Figure 1 shows the forecasted linear trend of GDP and Zakat proceeds in Bangladesh. Both variables seem to experience an upward trend until 2030; however, considering the linearity, after 2021, the collection Zakat proceeds is supposed to experience a downturn compared to economic growth in Bangladesh. This result is entirely based on assumption and could show the opposite direction as time passes. 


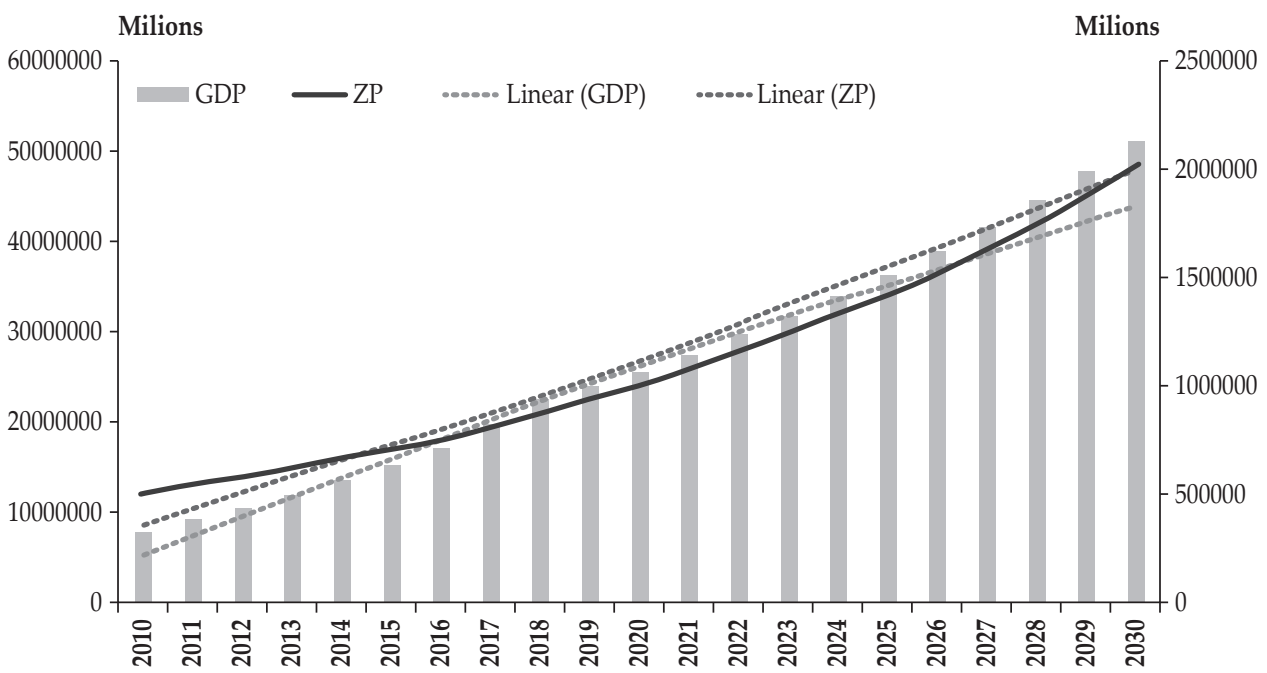

Source: Author's Computation

Figure 1.

Forecasted Linear Trend of GDP and Zakat Proceeds in Bangladesh

Before delving into the core statistical analysis, the measure of the data is required to obtain a more reasonable understating of the data sample (Table 5). Several particulars can be used to analyze the data; however, the study only explains the skewness and kurtosis of the data set. Skewness represents the symmetrical nature of data, in other words, lack of symmetry. Both of the variables are positively skewed, meaning the data set is skewed right; in other words, the left tail of the dataset is longer than the right tail. On the other hand, regarding the kurtosis, the data set is seen as negative, which indicates the flat distribution of data, meaning that the data is not normally distributed.

Table 5.

Descriptive Statistics

\begin{tabular}{lcc}
\hline Particulars & ZP & GDP \\
\hline Mean & $2.3253 \mathrm{E}+11$ & $2.68687 \mathrm{E}+13$ \\
Standard Error & 21260309111 & $2.92731 \mathrm{E}+12$ \\
Median & $2.1329 \mathrm{E}+11$ & $2.59104 \mathrm{E}+13$ \\
Standard Deviation & 97426975797 & $1.34146 \mathrm{E}+13$ \\
Sample Variance & $9.49202 \mathrm{E}+21$ & $1.79952 \mathrm{E}+26$ \\
Kurtosis & -0.886150753 & -1.048214158 \\
Skewness & 0.53512954 & 0.276848029 \\
Range & $3.14696 \mathrm{E}+11$ & $4.36166 \mathrm{E}+13$ \\
Minimum & $1.1 \mathrm{E}+11$ & $7.97539 \mathrm{E}+12$ \\
Maximum & $4.24696 \mathrm{E}+11$ & $5.1592 \mathrm{E}+13$ \\
Sum & $4.88313 \mathrm{E}+12$ & $5.64242 \mathrm{E}+14$ \\
\hline
\end{tabular}

Source: Author's Computation 


\subsection{Discussion}

In the overall development of any country, the contribution of social development plays a vital role, which is undeniable. For this reason, generally, in the manifesto of every development program, public or private, the priority of social development initiatives comes first; verily, Bangladesh is not different from this pattern. According to the International Labour Organization (ILO), Bangladesh has a significant pace in developing social indicators, where poverty reduction is an important factor. In 2018, according to the World Bank report, the poverty rate dropped to $8.3 \% \mathrm{v}$ from 14.3 in 2016 . As mentioned earlier in the paper, micro-credit programs take major credit for this achievement. With the poverty reduction, the number of school-going children, clean water facilities, and the infant mortality rate have significantly progressed as well. However, despite having this significant improvement in the various social indicators, the country is in dire need of social development with its current economic condition in order to reach the targeted goal.

The collected Zakat amount for 2018 shows a significant development of Zakat institutions and the participation of individuals in Bangladesh. This amount, if appropriately distributed, may influence society's class division; in other words, it may reduce the status gap or social inequality among people. Here, 'appropriately distributed' denotes the developmental mentality of the individual instead of showing off personality or a sense of pride. However, unfortunately, most of the distribution cases take place just for the show off; for that reason, the Zakat system has yet to experience the originality of its establishment in Bangladesh. On the other hand, this Zakat proceeds may help the people who are financially insolvent to establish small shops or vendor facilities to stand on their own feet and contribute to the economic development of Bangladesh.

Economic development is the core part of society's overall development. Therefore, what has been discussed above can also be under economic development. Noticeably, several entities or sectors can be influenced by the Zakat proceeds. For instance, Zakat somehow downgrades an individual's assets ownership by deducting a portion of the assets if the assets reach the nisab amount. In other words, it indirectly triggers the distribution of wealth, which ultimately alleviates the wealth gap between people. Besides, Zakat boosts the money circulation, the money which people hoard for the whole year. Later, this collected money is injected into the economy through various economic institutions. This money injection in the economy ultimately causes the upward shift of the demand curve; in other words, the supply curve also takes an upward shift. This upward shift of the supply curve then influences the production, employment, the establishment of new institutions and finally contributes to the rise of the country's GDP.

As mentioned earlier, there is a considerable alleviation of poverty in Bangladesh. However, it does not mean that the social status of people has been ameliorated accordingly. Through this Zakat proceeds, the government may arrange several training programs for the financially insolvent individuals who are unemployed and need assistance (definitely, it needs to fall under the eight categories of Zakat recipients). If Zakat proceeds influence the macro context of the economy, then there will be a development in human capital, which ultimately reduces the poverty gap and improve the economic condition of the country. The 
collected Zakat proceeds and its upper trend can help the government to alleviate the poverty rate in Bangladesh substantially.

\section{CONCLUSION AND RECOMMENDATION}

The main purpose of this study is to calculate the Zakat proceeds in Bangladesh using 2018 as a base. For the year 2018, the Zakat proceeds is estimated at almost one billion BDT (3.79\% of GDP) under the classical approach and less than one billion BDT (2.33\% of GDP) under the alternative approach.

Bangladesh has entered into the middle-income country group in 2021. To achieve this status, various initiatives and programs have been undertaken to reach the milestone; however, unfortunately, the Zakat program has not received the official recognition despite being a significant indicator for this development. It is still considered a pillar and a religious ritual or duty, and not an economic institution. However, respective authorities should recognize the Zakat institution as an economic institution to achieve sustainable development goals (SDGs), e.g., zero poverty rate.

The following initiatives should be considered (both at the individual and institutional level) when Zakat proceeds are distributed to the eligible recipients:

1) Zakat givers should develop a mentality to strengthen and change the economic status of the vulnerable group of the society.

2) They should target certain Zakat eligible individuals for each year for their economic well-being, instead of the whole group. The selection should be based on the earnings of the individuals and the number of members in their families.

3) The Zakat should not be limited to clothes and other one-time used products; instead, it should be distributed from an entrepreneurial perspective. In other words, the amount of Zakat should help a recipient to open a small business, e.g., vegetable vendor, tea stall, and fast food vendor.

In summary, nothing can be and will be changed or transformed without action. It is obvious that Bangladesh has a huge potential of Zakat proceed that can be the decisive and powerful instrument for poverty alleviation and development of the socio-economic condition. However, without a proper and genuine government and other related authorities' (public or private) intention to promote this institution, it will always be part of the study instead of practice. Therefore, it is high time for the government and other related authorities to accept the Zakat as a part of the mainstream economy for poverty alleviation and social integration in society to achieve sustainable social and economic growth. 


\section{REFERENCES}

Abu Bakar, N. B. (2007). A Zakat accounting standard (ZAS) for Malaysian companies. The American Journal of Islamic Social Sciences, 24(4), 74-92.

Adnan, M. A., \& Bakar, N. B. A. (2009). Accounting treatment for corporate Zakat: A critical review. International Journal of Islamic and Middle Eastern Finance and Management, 2(1), 32-45.

Adnan, M. S. G., Abdullah, A. Y. M., Dewan, A., \& Hall, J. W. (2020). The effects of changing land use and flood hazard on poverty in coastal Bangladesh. Land Use Policy, 99(December), 104868.

Al-Habshi, S. M. (2005). Zakat recognition and measurement of business wealth: An analysis of the growth condition. In B. Shanmugam, V. Perumal \& A. H. Ridzwa (Eds.), Issues in Islamic accounting. Serdang, Malaysia: University Putra Malaysia Press.

Al-Moghaiwli, M. H. (2001). Accounting for zakat and earnings management in Saudi Arabia. Journal of Accounting, Accountability and Performance, 7(1).

Al-Qaradawi, Y. (1999). Fiqh az-Zakat: A comparative study: The rules, regulations and philosophy of Zakat in the light of the Qur'an and Sunnah by Yusuf Al-Qaradawi. London: Dar Al Taqwa Ltd.

Awad, M. H. (1989). Adjusting tax structure to accommodate zakah. In I. M. Imtiazi, M. A. Mannan, M. A. Niaz \& A. H Deria (Eds.), Management of Zakah in modern Muslim society (pp. 77-96). Jeddah: IRTI-IDB.

Bahari, Z., \& Hamat, Z. (2004). Rethinking zakat on employment income: The case of Malaysia. 6th ASEAN Inter-University Seminars on Social Development, Penang, Malaysia, May 14-16.

Bangladesh Ministry of Finance. (2012). Poverty reduction programs in Bangladesh. https://mof.gov.bd/

Ben Jedidia, K., \& Guerbouj, K. (2021). Effects of zakat on the economic growth in selected Islamic countries: Empirical evidence. International Journal of Development Issues, 20(1), 126-142.

Firdaus, M., Beik, I. S., Irawan, T., \& Juanda, B. (2012). Economic estimation and determinations of Zakat potential in Indonesia. IRTI Working Paper Series: Vol. WP 1433-07, October 09, 2012.

Hassan, M. K., \& Khan, J. M. (2007). Zakat, external debt and poverty reduction strategy in Bangladesh. Journal of Economic Cooperation, 28(4), 1-38.

Islahi, A. A., \& Obaidullah, M. (2004). Zakah on stocks: Some unsettled issues. Journal of King Abdulaziz University: Islamic Economics, 17(2), 101-111.

Kahf, M. (1980). The calculation of Zakah for Muslims in North America. Plainfield, Indiana: Muslim Students' Association of the United States and Canada.

Kahf, M. (1987). Zakah estimation in some Muslim countries. Jeddah: IRTI-IDB, pp. 1-33. Available at http://monzer.kahf.com/papers.html.

Kahf, M. (1989). Zakat: Unresolved issues in the contemporary fiqh. IIUM Journal of Economics and Management, 2(1), 1-22.

Khan, F. (2009). Role of Zakah as an effective social safety net. Thoughts on Economics, 21(02), 28-29.

Khan, M. A. (1994). Accounting issues and concepts for Islamic banking in development of an accounting issues in Islamic banking. London: The Institute of Islamic Banking and Insurance, pp. 1-45. 
Khasandy, E. A., \& Badrudin, R. (2019). The influence of Zakat on economic growth and welfare society in Indonesia. Integrated Journal of Business and Economics, $3(1), 65-79$.

Khatun, S., Shaon, S. M., \& Sadekin, N. (2021). Impact of poverty and inequality on economic growth of Bangladesh. Journal of Economics and Sustainable Development, 12(10), 107-120.

Maîtrot, M., Wood, G., \& Devine, J. (2021). Understanding resilience: Lessons from lived experiences of extreme poverty in Bangladesh. Development Policy Review, 39(6), 894-910.

Mesbahuddin, T. (2010). Religion in development: An Islamic model emerging in Bangladesh. Journal of South Asian Development, 5(2), 221-241.

Mizanur Rahman, M. (2019). Participation as aid conditionality: Parliamentary engagement in Bangladesh's poverty reduction strategy. Asia Pacific Journal of Public Administration, 42(4), 230-236.

Mohamad, N., Hussin, N. E., \& Mohamad, N. M. (2020). The Impact of Zakat on economic growth in Malaysia. Journal of Islamic Economics and Law (JIEL), 1(2), 32-36.

Momen, M. D. N., \& Begum, M. (2006). Impact of micro credit program for women development in Bangladesh: A case study of BRAC. Asian Journal of Information Technology, 5(11), 1269-1283.

Mursyidi. (2003). Akuntansi Zakat kontemporer. Bandung: Remaja Rosdakarya.

Rahim, A., \& Rahman, A. (2007). Pre-requisites for effective integration of zakah into mainstream islamic financial system in Malaysia. Islamic Economic Studies, 14(1/2), 91-107.

Rahman, M. A., Halder, H. R., Rahman, M. S., \& \& Parvez, M. (2021). Poverty and childhood malnutrition: Evidence-based on a nationally representative survey of Bangladesh. Plos One, 16(8), 1-18.

Razak, M. I. M., Omar, R., Ismail, M., Hamzah, A. S., \& Hashim, M. A. (2013). Overview of Zakat collection in Malaysia; Regional analysis. American International Journal of Contemporary Research, 3(8), 140-148.

Sadeq, A. M. (1996). Ethico-economic institution of Zakah: An instrument of selfreliance and sustainable grassroot development. Humanomics, 12(2), 47-69.

Salama, A. A. (1990). Voluntary and compulsory applications of Zakat: A case study of Sudan 1405-1410 H. Third International Conference on Zakat, Kuala Lumpur, Malaysia, May 14-17.

Sarker, M. N. I., Yang, B., Tingzhi, W., Chakrovorty, A., Salam, M. A., \& Huda, N. (2020). Impacts of internal migration on poverty alleviation in Bangladesh. International Transaction Journal of Engineering, Management, \& Applied Sciences E Technologies, 11(11), 1-8.

Shaikh, S. A. (2015). Welfare potential of zakat: An attempt to estimate economy wide zakat collection in Pakistan. The Pakistan Development Review, 54(4), 10111027.

Shirazi, N. S. (2006). Providing for the resource shortfall for poverty elimination through the institution of Zakat in low-income Muslim countries. International Journal of Economics, Management and Accounting, 14(1), 1-27.

Shirazi, N. S., Amin, M. F. B., \& Anwar, T. (2009). Poverty elimination through potential Zakat collection in the OIC-member countries: Revisited [with Comments]. The Pakistan Development Review, 48(4), 739-754. 
Star Business Report. (2014). Multibillion-dollar zakat fund remains underused: study. The Daily Star. https://www.thedailystar.net/multibillion-dollar-zakat-fundremains-underused-study-17386

Sulaiman, M. (2003). The influence of riba and zakat on Islamic accounting. Indonesian Management and Accounting Review, 2(2), 149-167.

Suprayitno, E. (2020). The Impact of Zakat on economic growth in 5 State in Indonesia. International Journal of Islamic Banking and Finance Research, 4(1), 1-7.

Sydunnaher, S., Islam, K. S., \& Morshed, M. M. (2019). Spatiality of a multidimensional poverty index: A case study of Khulna City, Bangladesh. GeoJournal, 84, 1403-1416. https://doi.org/10.1007/s10708-018-9941-9

Uddin, A. E. (2016). Through Islamic banks' Zakat house (IBZH): Investment of Zakah funds in microfinance to remove poverty in Bangladesh: A new model. International Journal of Islamic Economics and Finance Studies, 2(1), 1-25.

World Bank. (2021). Bangladesh Overview. World Bank. https://www.worldbank. org/en/country/bangladesh/overview\#1

Zarqa, M. A. (2002). The role of Zakah in macro economy and fiscal policy. In M. Kahf (Ed.), Economics of Zakah. Jeddah: IRTI-IDB. 